NBER WORKING PAPER SERIES

\title{
SIMPLIFYING CHOICES IN DEFINED CONTRIBUTION RETIREMENT PLAN DESIGN
}

\author{
Donald B. Keim \\ Olivia S. Mitchell \\ Working Paper 21854 \\ http://www.nber.org/papers/w21854 \\ NATIONAL BUREAU OF ECONOMIC RESEARCH \\ 1050 Massachusetts Avenue \\ Cambridge, MA 02138 \\ January 2016
}

Research support for the analysis herein was provided by the TIAA-CREF Institute and by the Pension Research Council/Boettner Center at The Wharton School of the University of Pennsylvania. We are grateful for expert programming assistance from Louis Yang and Yong Yu, and for suggestions from Todd Gormley, Alex Michaelides, Jonathan Reuter, and participants at the Insight Summit of the AQR Institute at the London Business School. Opinions and conclusions expressed herein are solely those of the authors and do not represent the opinions or policy of the TIAA-CREF Institute, the National Bureau of Economic Research, or any institution with which the authors are affiliated. This research is part of the NBER program on Aging and workshop on Household Finance.

At least one co-author has disclosed a financial relationship of potential relevance for this research. Further information is available online at http://www.nber.org/papers/w21854.ack

NBER working papers are circulated for discussion and comment purposes. They have not been peerreviewed or been subject to the review by the NBER Board of Directors that accompanies official NBER publications.

(C) 2016 by Donald B. Keim and Olivia S. Mitchell. All rights reserved. Short sections of text, not to exceed two paragraphs, may be quoted without explicit permission provided that full credit, including (C) notice, is given to the source. 
Simplifying Choices in Defined Contribution Retirement Plan Design

Donald B. Keim and Olivia S. Mitchell

NBER Working Paper No. 21854

January 2016

JEL No. D14,E21,G11,J32

\begin{abstract}
In view of the growth and popularity of defined contribution pensions, along with the government's growing attention to retirement plan costs and investment choices provided, it is important to understand how people select their retirement plan investments. This paper shows how employees in a large firm altered their fund allocations when the employer streamlined its pension fund menu and deleted nearly half of the offered funds. Using administrative data, we examine the changes in plan participant investment choices that resulted from the streamlining and how these changes might affect participants' eventual retirement wellbeing. We show that streamlined participants' new allocations exhibited significantly lower within-fund turnover rates and expense ratios, and we estimate this could lead to aggregate savings for these participants over a 20 -year period of $\$ 20.2 \mathrm{M}$, or in excess of $\$ 9,400$ per participant. Moreover, after the reform, streamlined participants' portfolios held significantly less equity and exhibited significantly lower risks by way of reduced exposures to most systematic risk factors, compared to their non-streamlined counterparts.
\end{abstract}

Donald B. Keim

The Wharton School

Finance Department

University of Pennsylvania

3620 Locust Walk

Philadelphia, PA 19104-6367

keim@wharton.upenn.edu

Olivia S. Mitchell

University of Pennsylvania

The Wharton School

3620 Locust Walk, St 3000 SH-DH

Philadelphia, PA 19104-6302

and NBER

mitchelo@wharton.upenn.edu 


\section{Simplifying Choices in Defined Contribution Retirement Plan Design}

Working Americans have increasingly relied on employment-based defined contribution (DC) retirement plans as the more traditional defined benefit (DB) pensions have declined over the past 50 years. ${ }^{1}$ A distinguishing feature of DC plans in the U.S. is that participants must decide how much to contribute and where to invest their retirement assets, instead of holding the employer responsible for plan investments. Employees make these decisions within the menu of investment options offered by plan sponsors, and employers often automatically enroll participants into 'default' investments if people do not elect an option. Recent research in social psychology has argued that too many choices may create confusion, resulting in poorly-informed consumer decisions.

Relatively little is known about how changing the fund lineup can shape employee investment choices in DC plans. ${ }^{2}$ We seek to fill this gap using administrative data provided by a plan sponsor. The information enables us to examine how participants contributed to a menu of funds and what happened to their fund allocations, along with the costs and risks of the resulting portfolios, as a result of a firm-wide DC plan streamlining effort. In all, the plan menu in the firm was reduced considerably, with almost half of the funds deleted from the lineup. This streamlining process was intended to simplify the fund menu, but it is important to note that the average characteristics of the menu of offered funds (e.g., expense ratio, within-fund turnover, systematic

\footnotetext{
${ }^{1}$ The US Department of Labor (2014) reports that in 1975, 74\% of all participants in private sector plans were covered by DB plans; by 2012, only 6\% of participants were in DB pensions.

2 Various researchers have explored other aspects of plan design and participant behavior, including participation, contribution rates, and investment of employer stock; see for instance Choi et al., (2004), Mitchell and Utkus (2006), and Huberman et al. (2007). Additionally, prior analyses describe how participants who are automatically enrolled end up allocating their DC savings (Madrian and Shea, 2001).
} 
and idiosyncratic risk) were the same before and after the streamlining. In addition, this simplification made possible a more coherent categorization or 'tiering' of the retained funds.

We examine plan participants' investment choices prior to and after the streamlining event and evaluate what happened to participant fund allocations, risk exposure, and costs as a result of the reform. First, we explore what types of individuals held the deleted funds and how (if at all) they differed from other participants. Based on participant holdings on June 30, 2012, just before the changes were announced in July 2012, we define the holders of these deleted funds as the streamlined participants, and their counterparts as the non-streamlined participants. Second, we evaluate how streamlined participants responded to the changes, and how they reallocated their retirement assets after the reform. Third, we show how the streamlining process affected participants' portfolio turnover, risk, and expenses.

We find that participants subject to the streamlining proved to be older, more likely to be male, and higher-income; they also held higher balances in riskier funds and lower balances in safer balanced/target date funds. Participants holding the deleted funds either (a) reallocated their money to funds kept in the lineup in advance of the deadline to maintain a similar pre- and poststreamlining allocation, or (b) were defaulted into Target Date Funds (TDFs) resulting in an allocation containing, on average, safer assets. Only $9 \%$ of the streamlined participants $(\mathrm{N}=211)$ elected the new brokerage window (taking only $0.4 \%$ of their assets). Post-streamlining, the streamlined participants adjusted their portfolio holdings, ending up with fewer funds, significantly lower within-fund turnover rates, and lower expense ratios. Based on reasonable assumptions, these portfolio adjustments could lead to potential accumulated savings for these participants over a 20 -year period of $\$ 20.2 \mathrm{M}$, or more than $\$ 9,400$ per participant. Also, after the reform and relative 
to the non-streamlined participants, streamlined participants' portfolios generally exhibited lower diversifiable/idiosyncratic risk and less exposure to systematic/non-diversifiable risk factors.

In what follows, we first offer a brief literature review, followed by a discussion of our data and descriptive statistics. We then use multivariate regression models to estimate differences in the changes in portfolio characteristics and risks for participants affected by the streamlining compared to those who were not, controlling for several participant attributes. We conclude with thoughts on how a streamlining intervention such as this might shape employees' eventual retirement wellbeing.

\section{Related Prior Literature}

Financial economics suggests that participants in a pension plan should rationally focus on their own portfolios' risk-return profiles independent of the number of funds in their pension plan menu. Yet Benartzi and Thaler (2001) suggested that plan participants actually followed a naïve diversification approach, investing $1 / \mathrm{n}$ of their assets in each of the $n$ funds made available in the menu. Similarly suboptimal investment decisions were reported by Tang, Mitchell, Mottola, and Utkus (2010) who showed that even when plan sponsors offered a sufficiently diversified (efficient) menu of funds, participants regularly selected inadequately-diversified portfolios given their selected level of risk.

In addition, recent research in social psychology has argued that too many choices can create confusion and distraction, resulting in poorly-informed consumer decisions (e.g., Iyengar and Lepper, 2000). In the context of DC fund menus, Iyengar, Huberman, and Jiang (2004) asked whether such "choice overload" affected participant decisions in the 401(k) environment. They used a 2001 cross-section of data on 649 DC plans managed by the Vanguard Group to determine 
whether participation rates were lower in plans when more funds were on the menu. They found that, for every 10 additional funds on a menu, participation dropped two percent. While most of the plans examined had 10-30 options, participation rates were actually highest for those with 10 or fewer options.

In a follow-up analysis using the same dataset, Huberman and Jiang (2006) explored fund investment patterns rather than participation rates. There, conditional on participation, the authors concluded that (p. 763) "the number of funds used, typically between three and four, is not sensitive to the number of funds offered by the plans, which ranges from 4 to 59. A participant's propensity to allocate contributions to equity funds is not very sensitive to the fraction of equity funds among offered funds." They also reported that (p 765) "Once plans offer an abundance of choices (more than 10 funds), there is no correlation between equity allocation and exposure." Ultimately the authors concluded that plan sponsors need not be overly concerned about the length of the plan menu, as long as a reasonable diversity of options was included.

In a related study, Brown, Liang, and Weisbenner (2007) employed SEC 11-k filings on 891 plans from 1991-2000. The panel nature of their dataset permitted the authors to use fixedeffect regressions which confirmed that (p. 1995) "the number of equity and bond options in the 401(k) plan is an important predictor of contributions to equity and bond funds, respectively, even after accounting for firm-level fixed effects." They also found that, over the time period they examined, most funds added to 401(k) plans were expensive, actively-managed equity funds, resulting in higher average portfolio expenses and lower average portfolio performance. They concluded that (p. 2006) "the choice of investment options to make available in an individual accounts program is likely to have a first-order effect on the portfolio allocations that individuals make." 
In a more recent study, Morrin, Inman, Broniarczyk, Nenkov, and Reuter (2012) examined how employees covered by the Oregon University System DC plan altered their behavior when their plan menu was expanded from 10 to 19 fund choices. Both before and after the expansion, the default was a money market fund. When the smaller menu was offered, $21 \%$ defaulted to the money fund, while with the larger menu, 34\% defaulted. Accordingly, the authors concluded that offering more funds (p 548) "may be overwhelming for many investors." Of those who did make an election, participants selected on average 37\% (3.7 funds) of the funds from the 10 -fund menu, and $27 \%$ (5.3) from the 19 -fund menu. While those results did not support the $1 / \mathrm{n}$ heuristic, they were consistent with perhaps a weaker form of the heuristic whereby increasing the number of offered funds led participants to hold more funds. Moreover, the authors (p. 547) concluded that it is sensible for plan sponsors to offer a sufficient variety of choices, but there is a need to "clearly categorize the options to help the [participants] perceive the set of offerings at a higher, more abstract level. Partitioning the funds may enhance asset class diversification while not reducing (and actually increasing) the total number of funds invested in. Subjectively grouping funds by asset class is more likely to assist novice investors than expert investors in their financial decision making."

In sum, research to date has provided mixed conclusions about how the number and mix of DC fund options influences investment patterns in retirement accounts, and little to no evidence on how differences in the fund options affect costs and risks of participant portfolios. ${ }^{3}$ Moreover, no study has yet examined how participants react to a rather substantial reduction of retirement plan investment choices. In what follows, we explore these issues with a unique new administrative

${ }^{3}$ See also Beshears et al. (2013) who evaluated how a simple saving rate and asset allocation protocol in a DC plan affects the probability of participating and contribution rates conditional on participation; they did not, however, look at asset allocation patterns. 
dataset that permits us to follow investor behavior before and after a substantial streamlining in the fund menu and document the effects of the reform on the costs and risks associated with participants' portfolios.

\section{The Setting}

The employer we study is a large US nonprofit institution. Like its peers, it has long offered a DC structure to cater to participants' retirement saving needs on a pre-tax basis. Prior to 2013, the plan included almost 90 mutual funds in the investment menu, ranging from equity to target date to bond index funds, as well as REIT, commodity, and other sector funds. Cognizant of the growing literature on choice overload (see references in section 1), the firm's investment committee in 2011 determined that a shorter list of offered funds would be easier to administer, explain, and rationalize, compared to the prior menu.

To this end, the committee streamlined the plan menu and constructed a four-tiered structure for the remaining funds. Participants who had invested in the funds that would be eliminated from the menu would be allowed to reallocate their assets and contributions to any other fund in the menu, and anyone who did not move his assets out of the funds to be deleted would have his assets automatically transferred to the age-appropriate Target Date Fund (TDF). ${ }^{4}$ Alternatively, participants who elected to do so could move their assets to a new self-directed brokerage account within the plan which would give them access to not only the closed funds, but also thousands of other mutual funds.

\footnotetext{
${ }^{4}$ This was defined as the TDF with the target date closest to the year the participant would attain age 65. Under the Pension Protection Act of 2006, the US Department of Labor permits TDFs as QDIAs (qualified default investment alternatives) that can be used for participants who do not elect their own investment mix.
} 
The result was the elimination of 39 funds from the initial lineup, based on the funds' expense ratios and the number of participants and aggregate amount invested in each fund. ${ }^{5}$ Remaining funds were allocated across a new four-tier structure, where each successive tier would afford participants additional choice. Tier 1, selected as the default tier for participants not actively electing an investment mix, included 13 low-cost Target Date Funds. Additional tiers offered increasing flexibility of choice for participants seeking to make more customized and sophisticated allocations. Tier 2 included four indexed funds: Money Market, U.S. Diversified Stocks, U.S. Bonds, and Diversified International Stocks. Tier 3 included 32 funds arranged into separate "risk" categories illustrated in more detail in Table 1 . The range of categories included: small/mid/largecap and value/growth stock funds; small/mid/large-cap international stock funds; short/intermediate/long-maturity and Treasury/corporate bond funds; balanced funds; and a passive equity REIT fund to provide access to the real estate asset class. Tier 4 constituted the brokerage account.

[Table 1 here]

The plan sponsor announced its streamlined fund lineup in July 2012, with an implementation date of mid-October 2012. In addition to a newsletter sent to all participants, the employer created a custom website, broadcasted online webinars, sent targeted emails, held participant meetings, and sent hard copy mail to explain the changes.

\section{Data and Descriptive Statistics}

\footnotetext{
${ }^{5}$ In results not reported here (available on request) we find that the average characteristics of the menu of offered funds (e.g., expense ratios, within-fund turnover rates, and systematic and idiosyncratic risk) were not significantly different before versus after the streamlining.
} 
To analyze the change in behavior post- versus pre-streamlining, we obtained access to information on the retirement plan account balances and periodic contributions of all the (identitycensored) participants. Our administrative dataset included information on contributions, balances, and asset allocation prior to the streamlining, defined in our analysis below as end-June 2012, and after the change, defined as end-December 2012. To this file we appended information from public sources (via ticker and CUSIP numbers) for each fund's equity fraction and style (bond, balanced, stock, etc.), as well as monthly return histories. The fund administrator also provided individual demographic information on participants' age, sex, education (highest degree from graduate school versus less than graduate school), and, from external sources, imputed household income (assigned according to the participant's zip codes, where low $<\$ 50 \mathrm{~K}$, middle $\$ 50-100 \mathrm{~K}$, and high $>\$ 100 \mathrm{~K}){ }^{6}$

Using the participant balance and contribution data, we identify participants whose holdings were directly affected by the streamlining. Specifically, we separate participants into a Streamlined group - those participants who held funds at end-April 2012 that were subsequently deleted due to streamlining - and a Non-Streamlined group. Additionally, we separate the streamlined participants into two subgroups: "Plan-Defaulted \& Streamlined" are the streamlined participants who took no action after the announced streamlining and were defaulted by the Plan into an age-appropriate TDF at the October deadline; and "Not-Plan-Defaulted \& Streamlined" are the streamlined participants who exchanged out of the deleted funds prior to the October deadline.

To illustrate how the reform worked, we begin by reviewing descriptive statistics on the balances in the retained and deleted funds by risk category, and we also compare key attributes of

\footnotetext{
${ }^{6}$ These were derived from data supplied to the plan administrator from IXI Corporation and derived from zip+4 Census tract information. (See http://www.ixicorp.com/products-andservices/customer-targeting-and-scoring/wealthcomplete/)
} 
participants and their retirement plan investments as of end-June 2012 (our baseline). Table 2 reports aggregate balances held in retained and deleted funds by risk category, where of the almost $\$ 1$ billion invested at end-June 2012, most of the assets (80\%) were held in retained funds. Overall, $20 \%$ of the total assets were in funds that were subsequently deleted; of those, about $60 \%$ had been in equity (stock, balanced, or international) funds, $24 \%$ in alternatives/sector funds, and $14 \%$ in bond funds (with the remainder in money market funds).

[Table 2 here]

In Table 3 we report aggregate dollar balances, the number of total participants, and the number of funds held by all plan participants at end-June 2012 (rightmost column), along with the same information for the streamlined participants (who owned at least one deleted fund) and the non-streamlined participants (who owned no deleted funds). The number of participants in each group was roughly similar (2,238 versus 2,371$)$, but the streamlined group had accumulated almost $60 \%$ more in assets ( $\$ 603.8$ versus $\$ 380.0$ million), contributed $30 \%$ more on a monthly basis (\$1802 versus \$1356 per participant), and held more funds overall (87 in total versus 47). On average, about one-third of the contributions of the streamlined participants were in funds that were subsequently deleted and two-thirds in retained funds.

[Table 3 here]

A comparison of characteristics for streamlined versus non-streamlined active participants appears in Table 4. The streamlined participants were significantly older, more likely to be male, lived in higher-income households, and were more likely to have earned graduate-level degrees. They also owned three times as many funds (an average of 6.8 versus 2.1 ) compared to the nonstreamlined participants. Regarding asset allocations, Table 5 indicates that the streamlined participants were more likely to contribute directly to stock funds (sector, domestic and 
international), while the non-streamlined participants were more likely to obtain equity exposure (indirectly and in more conservative amounts) via significantly larger allocations to target date funds. ${ }^{7}$ As a result, on average, the streamlined participants held portfolios containing more equity exposure.

[Tables 4 and 5 here]

\section{Changes in Portfolio Allocations: A First Look}

Table 6 reports how participants changed their retirement plan portfolios after the streamlining went into effect. In particular, we compare the allocation of retirement plan assets at two time points: prior to (as of end-June 2012), and after streamlining (as of end-December 2012). Overall, non-streamlined participants kept contributions to their retirement accounts virtually unchanged (column 3). Because these participants were not directly affected by the elimination of funds from the lineup, their persistence in the surviving funds refutes the idea that the reorganization and tiering of the surviving funds might have affected all participants' behavior. ${ }^{8}$

[Table 6 here]

By contrast, streamlining produced statistically significant and economically meaningful changes to allocations made by streamlined participants. To more clearly assess the allocation adjustment process, we separate this group into two sub-samples: (a) those streamlined participants who did not take full advantage of the window between the announcement in July and the deadline

\footnotetext{
${ }^{7}$ Given the age profile of the non-streamlined sample, the average equity share of their investment in TDFs was just under $80 \%$.

${ }^{8}$ Although contributions by non-streamlined participants did increase for stock funds and decrease for "other" funds, the changes were economically tiny $(0.4 \%$ and $0.1 \%$ respectively). In results not reported here, we also find that fund allocations by non-streamlined participants did not change significantly by the end of either 2012 or 2013 , in terms of both contributions and balances.
} 
for action on October 19 and hence were defaulted by the Plan into age-appropriate target date funds (Plan-Defaulted \& streamlined); and (b) those streamlined participants who exchanged out of the deleted funds during the July-October 19 window (Not-Plan-Defaulted \& streamlined). The results for both streamlined groups are reported in the first two columns in Table 6. Both types of streamlined participants significantly reduced allocations to stock, sector, and international funds and they shifted contributions mainly to TDFs. The changes were more pronounced, however, for the Plan-Defaulted members of the streamlined sample: their allocations to stock, sector, international, balanced and bond funds fell significantly - by a combined $35.6 \%$ reduction in contributions, and their allocations to TDFs rose by $35.3 \%$. By contrast, the Not-Plan-Defaulted streamlined participants significantly decreased allocations to stock, sector and international funds (a combined $17.8 \%$ reduction) and significantly increased contributions to TDFs by $13.8 \%$. The Not-Plan-Defaulted group also re-allocated a significant $2 \%$ of its contributions to the new brokerage account. ${ }^{9}$ Although we cannot see the transactions in these brokerage accounts, we surmise that this shift in contributions reflects efforts by the Not-Plan-Defaulted group to continue investing in funds now eliminated from the Plan's menu. ${ }^{10}$

\footnotetext{
9 The amount re-allocated to brokerage accounts, $\$ 2.7 \mathrm{M}$, represents a small portion of the plan's aggregate assets and few participants: only $9 \%$ of those holding deleted funds prior to the change subsequently opened a brokerage account following the change. This may be because, at the time the brokerage accounts were announced, restrictions were imposed on the number of exchanges permitted in and out of certain funds each year. Also participants were informed that holdings in the brokerage account would incur special redemption fees of $1 \%$ (minimum $\$ 50$, maximum $\$ 250$ ) for no-transaction-fee funds; for transaction-fee funds, the participant would be charged $\$ 20$ per transaction. These fees were eliminated prior to the actual change. In both cases the minimum investment was $\$ 1,000$. Additional loads would depend on the share classes elected by each participant. This lack of participation in brokerage accounts reported here is consistent with broader evidence for DC plans reported in Vanguard (2015).

${ }^{10}$ This large reallocation by both streamlined groups is expected given they were the participants holding the deleted funds. But it is interesting to note that the streamlined participants were also the more active traders - in terms of number of fund exchanges - during the year prior to the announcement of the streamlining. During the period July 2011 to June 2012, the Not-Plan-
} 
Table 7 helps us examine whether the pre- versus post-streamlining re-allocations were different for high versus low household income participants. ${ }^{11}$ In the Non-Streamlined group there is little evidence of differences by income pre- versus post-streamlining re-allocations; one exception is that low-income members of the Non-Streamlined group were more likely to shift allocations out of bond funds into the other available funds, although the magnitudes are very small (less than 1\%). Within the Streamlined group, significant differences in re-allocations between high and low-income participants are mainly in the Plan-Defaulted sub-group. The most interesting finding, both statistically and economically, is that the overall re-allocations into TDFs seen in Table 6 prove to be $10 \%$ larger, and the re-allocations out of stock funds $7.6 \%$ larger, for the low-income members of the Plan-Defaulted group. In other words, the streamlining reform had a larger impact on low-income savers, making their portfolios better balanced and less risky than before.

[Table 7 here]

\section{Changes in Participant Portfolio Characteristics and Risks: Multivariate Analysis}

Next we use multivariate regression analyses to analyze in more detail how the reform shaped changes in the portfolio characteristics and risks of streamlined and non-streamlined participants. To measure these differences, we again separate the streamlined from the non-

Defaulted \& streamlined (Plan-Defaulted \& streamlined) participants averaged 2.39 (1.9) fund exchanges per month, compared to 0.9 exchanges on average for the Not-Streamlined participants. ${ }^{11}$ Recall, from section 3, that the low income group had household income of $<\$ 50 \mathrm{~K}$; the middle group $\$ 50-100 \mathrm{~K}$; and the high income group $>\$ 100 \mathrm{~K}$. 
streamlined participants, and we further identify the two sub-groups of streamlined participants with zero-one indicator variables, the Plan-Defaulted-Streamlined and the Not-Plan-DefaultedStreamlined. Our analysis also controls for various participant attributes including age and agesquared (to test for possible nonlinear effects); male or female; educational level (graduate degree or not); and high versus low household income. We estimate the change in portfolio characteristics over two intervals: end-June 2012 to end-December 2012 (the same time period analyzed in Tables 6 and 7); and also end-June 2012 to end-December 2013 (a longer interval that allows more time for participants to adjust their portfolio allocations post-streamlining).

\subsection{Changes in Portfolio Characteristics}

Table 8 compares the effects of the reform on participant portfolio turnover rates, expense ratios, number of funds held, and percentage allocation to stocks, in portfolios held by streamlined versus non-streamlined participants. Panel A (B) reports model estimates for the shorter (longer) post-streamlining period.

[Table 8 here]

Over the shorter interval (Panel 8A), we find that, relative to their unaffected counterparts, Streamlined participants - both those that were Plan-Defaulted and those that were not experienced significantly greater reductions in portfolio turnover, larger reductions in expense ratios, and a larger decline in the number of funds held. Moreover, these reductions were generally larger for the subset of streamlined participants that were Not-Plan-Defaulted. For example, the reduction in the expense ratio was 6.0 (3.1) bps larger for the Not-Plan-Defaulted (Plan-Defaulted) streamlined participants than for non-streamlined, and the difference of $2.9 \mathrm{bps}$ is significant at the 0.01 level. This last result might be partly due to our inability to observe brokerage window transactions in which these Not-Plan-Defaulted participants might have replicated their prior fund 
allocations and associated higher expense ratios. That said, recall that very few Not-Plan-Defaulted participants opened brokerage accounts; and virtually none of the Plan-Defaulted participants.

In contrast to the findings for the other characteristics in Table $8 \mathrm{~A}$, the changes in the percentage of the portfolio allocated to stocks over the shorter interval were markedly different for the Not-Plan-Defaulted and the Plan-Defaulted streamlined subsamples relative to their nonstreamlined counterparts. Specifically, the Plan-Defaulted streamlined participants significantly increased their stock allocations by $1.3 \%$ by the end of December 2012, while the Not-PlanDefaulted streamlined group experienced a statistically and economically significant $4.8 \%$ reduction in stock allocation as a result of the streamlining. This difference of $6.1 \%$ is statistically significant at the 0.01 level, and it is consistent with Table 6 where we found: (a) a significant reduction in stock and sector fund allocations by the Not-Plan-Defaulted streamlined participants; and (b) a significant increased allocation by the Plan-Defaulted streamlined participants to TDFs which contain a much higher percentage of stocks ${ }^{12}$ than the more conservative bond and balanced funds which they dropped, post- streamlining.

We also find that the reductions in stock allocations and number of funds held were greater for men than for women, consistent with Barber and Odean's (2001) finding for discount brokerage accounts that individual male investors trade stocks more aggressively than do female investors.

The message of Panel 8B is simple: the changes in portfolio characteristics caused by the reform that were evident over the shorter interval in Panel A largely persisted over the entire 2013 calendar year. The one exception is that, during 2013, the Not-Plan-Defaulted streamlined participants reversed the initial reduction in their stock market exposure, so that by the end of

\footnotetext{
${ }^{12}$ Sixty percent of the Plan-Defaulted streamlined group was under the age of 60 . The average
} equity percent in the TDFs for this age range is about $86 \%$. 
2013, their stock exposure was not significantly different than beforehand. Otherwise, the initial effects of the reform (e.g., lower turnover and expense ratios) were not undone by participant transactions over the subsequent twelve months.

Not only are these effects statistically significant: they are also economically important. That is, the (unconditional) average reduction in the annual expense ratio for the entire streamlined group was $4.0 \mathrm{bp}(=27.9 \mathrm{bp}-23.9 \mathrm{bp})$, or a $\$ 0.242 \mathrm{M}$ annual cost savings (based on the prestreamlining balance for the streamlined group of $\$ 603.8 \mathrm{M}$ at end-June 2012). Since the average age of the streamlined participants was 49 in April 2012, if those savings could be achieved on an ongoing basis over 20 years and reinvested at $5 \%$ annually, the accumulated benefit would amount to $\$ 8.40 \mathrm{M}$ or around $\$ 4,000$ per participant. Additionally, the (unconditional) average decline in within-fund annual turnover for the streamlined group was $11.3 \%(=35.2 \%-23.9 \%)$. Based on the streamlined group balance of $\$ 603.8 \mathrm{M}$ at end-June 2012 and assuming round-trip within-fund transaction costs of $0.50 \%$, this could translate into an annual aggregate cost savings of $\$ 0.341 \mathrm{M}^{13}$ If such savings could be achieved on an ongoing basis over 20 years and reinvested at $5 \%$ annually, the accumulated additional benefit would be $\$ 11.8 \mathrm{M}$, or $\$ 5,400$ per participant. In total, then, the per-participant savings could be over $\$ 9,400$ per participant.

\subsection{Changes in Portfolio Risks}

We also examine how participant portfolio risks changed by comparing pre- versus poststreamlining positions. To this end, we first estimate the factor-related systematic risks and diversifiable (idiosyncratic) risks for both retained and deleted funds, using a model similar to Fama-French (1993) in which the estimated coefficients measure each fund's exposures to systematic factor risks:

\footnotetext{
${ }^{13}$ We compute this as $\$ 603.8 \times(0.113 \times 2 \times 0.025)$.
} 


$$
\widetilde{R}_{i t}-R_{F t}=\alpha+b_{1}\left(\widetilde{R}_{M t}-R_{F t}\right)+b_{2} S m B_{t}+b_{3} H m L_{t}+b_{4} W m L_{t}+b_{5} \text { Term }_{t}+b_{6} \text { Def } f_{t}+\widetilde{e}_{i t}
$$

Here $\tilde{R}_{i t}-R_{F t}$ refers to the excess return of fund $i$ over the risk-free rate (the one-month Treasury bill rate from Ibbotson Associates); $\widetilde{R}_{M t}-R_{F t}$ refers to the value-weighted return on all NYSE, AMEX, and NASDAQ stocks (from CRSP) minus the risk-free rate; SmB refers to the difference in the performance of small relative to big stocks; $H m L$ to the difference in performance of value stocks to growth stocks; $W m L$ is a momentum factor premium measuring the difference in performance of past winner and past loser stocks; Term measures the difference between the monthly long-term government bond return (from Ibbotson Associates) and the one-month Treasury bill rate measured at the end of the previous month (from the Center for Research in Security Prices, CRSP); and Def measures the difference between the return on a market portfolio of long-term corporate bonds (the Composite portfolio in the corporate bond module of Ibbotson Associates) and the monthly long-term Treasury bond return. The fund's diversifiable (idiosyncratic) risk is measured as $\sigma(e)$, the standard deviation of the regression residuals. These regressions are estimated using ten years of monthly fund and factor returns.

Having estimated the model parameters representing systematic and idiosyncratic risks, we next compute for each participant the systematic and idiosyncratic risks specific to his own portfolio, using his portfolio weights as of end-June 2012 and end-December 2012. Finally, we regress the post-pre changes in systematic and idiosyncratic risks on Not-Plan-DefaultedStreamlined, Plan-Defaulted-Streamlined, and our control variables. Results appear in Table 9, where Panel A (B) reports model estimates for the shorter (longer) post-streamlining period.

\section{[Table 9 here]}

Table 9A shows that, as a result of the reform, all streamlined participants' portfolios (both Plan-Defaulted and Not-Plan-Defaulted) generally exhibited significantly greater reductions in 
systematic risk relative to the non-streamlined participants. Stated differently, there was a larger reduction in portfolio 'tilt' toward most systematic sources of variation for the streamlined participants. There are two exceptions. First, relative to the non-streamlined group, there was a significant increase in market beta for the Plan-Defaulted streamlined participants, in contrast to the significant decrease in market beta for the Not-Plan-Defaulted streamlined participants. This tracks the changes in broad stock market exposure for these two streamlined groups shown in Table 8. Second, and again relative to the non-streamlined group, we find a greater increase (reduction) in small-cap risk exposure for the Not-Plan-Defaulted (Plan-Defaulted) streamlined participants. The reason for this difference is not entirely clear from Tables 6 and 8 where the stock exposures and allocations are reported with insufficient granularity to differentiate the presence of small- versus large-cap stocks. One possible explanation, though, is that many of the deleted sector and international funds, in which the Not-Plan-Defaulted streamlined group had been invested, had much lower exposures to small-cap risk.

We also find that the reform resulted in a significant reduction in idiosyncratic risk for the streamlined group relative to their non-streamlined peers, and this reduction was even more notable for the Not-Plan-Defaulted members of the streamlined group. Moreover, the reduction in idiosyncratic risk was greater for male versus female participants, as were reductions in exposures to the market and momentum stock risk factors, and the default risk bond factor. These last two findings in the retirement plan setting agree with Barber and Odean's results (2001) for online brokerage accounts. It is also worth pointing out that many of these changes in risk exposure were most pronounced for participants with larger, versus smaller, portfolio balances. ${ }^{14}$

\footnotetext{
${ }^{14}$ This pattern aligns with results by Calvet, Campbell, and Sodini (2009) who studied Swedish investors; they found that wealthier investors rebalanced toward a riskier share when they altered their portfolios. Yet that analysis was not focused on retirement accounts, as here, however.
} 
As was true for the observed portfolio characteristics discussed above, Table 9B confirms that the Panel A shorter-period portfolio risk changes wrought by the reform persisted over the entire 2013 calendar year. The main exception, consistent with our findings in Table 8B, is that the Not-Plan-Defaulted streamlined participants reversed their initial reduction in stock market exposure post-reform, so that by the end of 2013 their market beta was actually significantly larger than before the streamlining. Also both streamlined groups reversed their initial reduction in tilt toward value stocks $(\Delta \beta(\mathrm{HmL})$ in Table $9 \mathrm{~A})$ and ended 2013 with significantly larger value stock exposure, relative to the non-streamlined group. It is also worth noting that the reduction in idiosyncratic risk for both streamlined groups reported for the shorter interval remains significant over the longer interval, although the change was smaller. Thus the initial effects of the reform remained largely intact by the end of 2013.

To summarize the results in this section, the streamlining of the DC plan described here had a statistically significant and economically important impact on the characteristics and risk attributes of savers' accounts. Specifically, within-fund turnover in participants' retirement portfolios (a significant cause of largely unseen transaction costs) and expense ratios were significantly reduced; and many dimensions of systematic/non-diversifiable risk, as well as idiosyncratic/diversifiable risk, were also significantly curtailed. As such, our results complement and extend previous studies suggesting that plan simplification enhances retirement saving (e.g., Beshears et al. 2013), though previous work has focused only on participation and contributions, but not on asset allocation outcomes as here.

\section{Conclusions}


This study has examined the salutary effects of streamlining the DC fund menu by deleting some funds and tiering options in an easier-to-understand format. While recent studies have evaluated how simplification can influence retirement plan participation and contributions, they have not examined how streamlining changes investment patterns. Our analysis examines how halving the fund menu while including a new brokerage account changed investment behavior at a large nonprofit institution. We find that participants who initially held at least one deleted fund were relatively older, more likely to be male, and earned higher incomes; they also held higher balances in riskier funds and lower balances in safer/balanced/target date funds. Interestingly, in response to the changed lineup, only $9 \%$ of these participants moved any money at all into the new brokerage window, taking only $0.4 \%$ of assets. Moreover, streamlined participants' new allocations included significantly fewer funds and had significantly lower exposure to non-market systematic risks; they also contained a lower allocation to stocks. Streamlined participants' new allocations also led to fund holdings with significantly lower expense ratios and within-fund turnover rates, which, based on reasonable assumptions, could lead to potential accumulated savings for these participants over a 20 -year period of $\$ 20.2 \mathrm{M}$, or over $\$ 9,400$ per participant.

The changes we have discerned are important, particularly given regulators' growing interest in retirement plan fees and costs. As one example, recent US Department of Labor guidance to plan participants alerted members to the possibility that costs may rise as investment options become more numerous. ${ }^{15}$ Such costs, in turn, can reduce the size of the nest egg available

15 For instance, the US Department of Labor (US DOL) states on its website (http://www.dol.gov/ebsa/publications/401k_employee.html): "In recent years, there has been a dramatic increase in the number of investment options typically offered under 401(k) plans as well as the level and types of services provided to participants. These changes give today's employees who direct their 401(k) investments greater opportunity than ever before to affect their retirement savings. As a participant you may welcome the variety of investment options and the additional 
for retirement. Additionally, employers in their plan fiduciary capacity are charged under pension law with managing retirement plans in the best interests of participants. ${ }^{16}$ Our work implies that plan sponsors would do well to recognize that the length and complexity of their plan menus matter. Accordingly, our results should be of substantial interest to those seeking to improve defined contribution retirement plan design, including employers, fund providers, consultants, and regulators.

services, but you may not be aware of their cost. As shown above, the cumulative effect of the fees and expenses on your retirement savings can be substantial."

${ }^{16}$ The US DOL points out that plan sponsors must "ensure that fees paid to service providers and other expenses of the plan are reasonable in light of the level and quality of services provided; and select investment options that are prudent and adequately diversified; disclose plan, investment, and fee information to participants to make informed decisions regarding their investment options under the plan; and monitor investment options and service providers once selected to see that they continue to be appropriate choices."

(http://www.dol.gov/ebsa/publications/401k_employee.html) 


\section{References}

Barber, B. and T. Odean. 2001. "Boys will be Boys: Gender, Overconfidence, and Common Stock Investment" Quarterly Journal of Economics 116(1): 261-292

Benartzi, S., and R. Thaler. 2001. "Na1ve Diversification Strategies in Defined Contribution Saving Plans. American Economic Review. 91(1): 79-98.

Beshears, J., J. Choi, D. Laibson, and B. Madrian. 2013. "Simplification and Saving." Journal of Economic Behavior \& Organization 95 (November): 130- 145

Brown, J., N. Liang, and S. Weisbenner. 2007. "Individual Account Investment Options and Portfolio Choice: Behavioral Lessons from 401(k) Plans." Journal of Public Economics. 91(10): 1992-2013.

Calvet, Laurent E. John Y. Campbell, and Paolo Sodini. 2009. Fight or Flight? Portfolio Rebalancing by Individual Investors. Quarterly Journal of Economics. 124 (1): 301-348.

Choi, J., D. Laibson, and B. Madrian. 2004. "Plan Design and 401(k) Savings Outcomes." National Tax Journal 57(2): 275-298.

Fama, Eugene and Kenneth R. French. (1993). "Common Risk Factors in the Returns on Stocks and Bonds." Journal of Financial Economics 33(1): 3-56.

Huberman, G., S. Iyengar, and W. Jiang, W. 2007. Defined Contribution Pension Plans: Determinants of Participation and Contribution Rates. Journal of Financial Services Research, 31(1): 1-32.

Huberman, G. and W. Jiang. 2006. "Offering vs. Choice in 401(k) Plans: Equity Exposure and Number of Funds." Journal of Finance. 61(2): 763-801.

Iyengar, Sheena S. and Mark Lepper. 2000. "When Choice is Demotivating: Can One Desire Too Much of a Good Thing?” Journal of Personality and Social Psychology 76(9): 995-1006.

Iyengar, S., W. Jiang, and G. Huberman. 2004. "How Much Choice is Too Much?: Contributions to 401(k) Retirement Plans." In Pension Design and Structure: New Lessons from Behavioral Finance. Eds. O. S. Mitchell and S. P. Utkus. Oxford University Press: 83-95.

Madrian, B., and D. Shea. 2001. "The Power of Suggestion: Inertia in 401(k) Participation and Saving Behavior." Quarterly Journal of Economics 116(4): 1149-1187.

Mitchell, O. S., and S. P. Utkus. 2006. "How Behavioral Finance Can Inform Retirement Plan Design.” Journal of Applied Corporate Finance. 18(1): 82-94

Mitchell, O. S. and S. P. Utkus. 2012. "Target-Date Funds and Portfolio Selection in 401(k) Plans." NBER WP 17911. 
Morrin, M., J. Inman, S. Broniarczyk, G. Nenkov, and J. Reuter. 2012. "Investing for Retirement: The Moderating Effect of Fund Assortment Size on the 1/N Heuristic." Journal of Marketing Research 49(4): 537-550.

Tang, N., O.S. Mitchell, G. Mottola, and S. Utkus. (2010). "The Efficiency of Sponsor and Participant Portfolio Choices in 401(k) Plans." Journal of Public Economics. 94(11-12): 10731085

US Department of Labor (US DOL). nd. "A Look At 401(k) Plan Fees.”

http://www.dol.gov/ebsa/publications/401k_employee.html

US Department of Labor (US DOL). 2014. "Private Pension Plan Bulletin Historical Tables and Graphs.” Employee Benefits Security Administration, September.

http://www.dol.gov/ebsa/pdf/historicaltables.pdf

Vanguard. (2015). "The Brokerage Option in DC Plans." Vanguard Research Note, June. https://institutional.vanguard.com/iam/pdf/RNBKDCP.pdf 


\section{Table 1. Description of Fund Menu Post- (and Pre-) Streamlining}

Tier $1: 13$ Target Date Funds

Tier 2 : 4 Funds (Money Market, U.S. Diversified Stocks, U.S. Bonds, Int'1 Stocks) ${ }^{1}$

Tier $3: 32$ Funds [Number of funds kept (Number of funds eliminated)] ${ }^{2}$

Bond Funds

Treasury

Corporate

Other Bonds (High Yield)

Stock Funds

Diversified

Value

Growth

Balanced Funds

International Stock Funds

Other (Althernative Assets, Sector Funds)

\begin{tabular}{ccc} 
Short & Intermed & Long \\
\hline $0(2)$ & $2(1)$ & $1(1)$ \\
$1(1)$ & $1(1)$ & $2(0)$ \\
$1(0)$ & &
\end{tabular}

\begin{tabular}{ccc} 
Large & Mid-Cap & Small \\
\hline $1(3)$ & $3(0)$ & $1(0)$ \\
$3(9)$ & $1(1)$ & $1(3)$ \\
$4(2)$ & $1(1)$ & $2(1)$
\end{tabular}

$2(2)$

$1(3) \quad 2(2) \quad 1(2)$

$1(4)$

${ }^{1}$ Three Money Market funds were eliminated.

${ }^{2}$ Thirty-nine funds were eliminated.

Note: Post (pre) allocation computed as of end-December (June) 2012.

Source: Authors' calculations. 
Table 2. Total Balances in Retained (and Deleted) Funds by Risk Category (as of end-June 2012; $\$ \mathrm{M})$

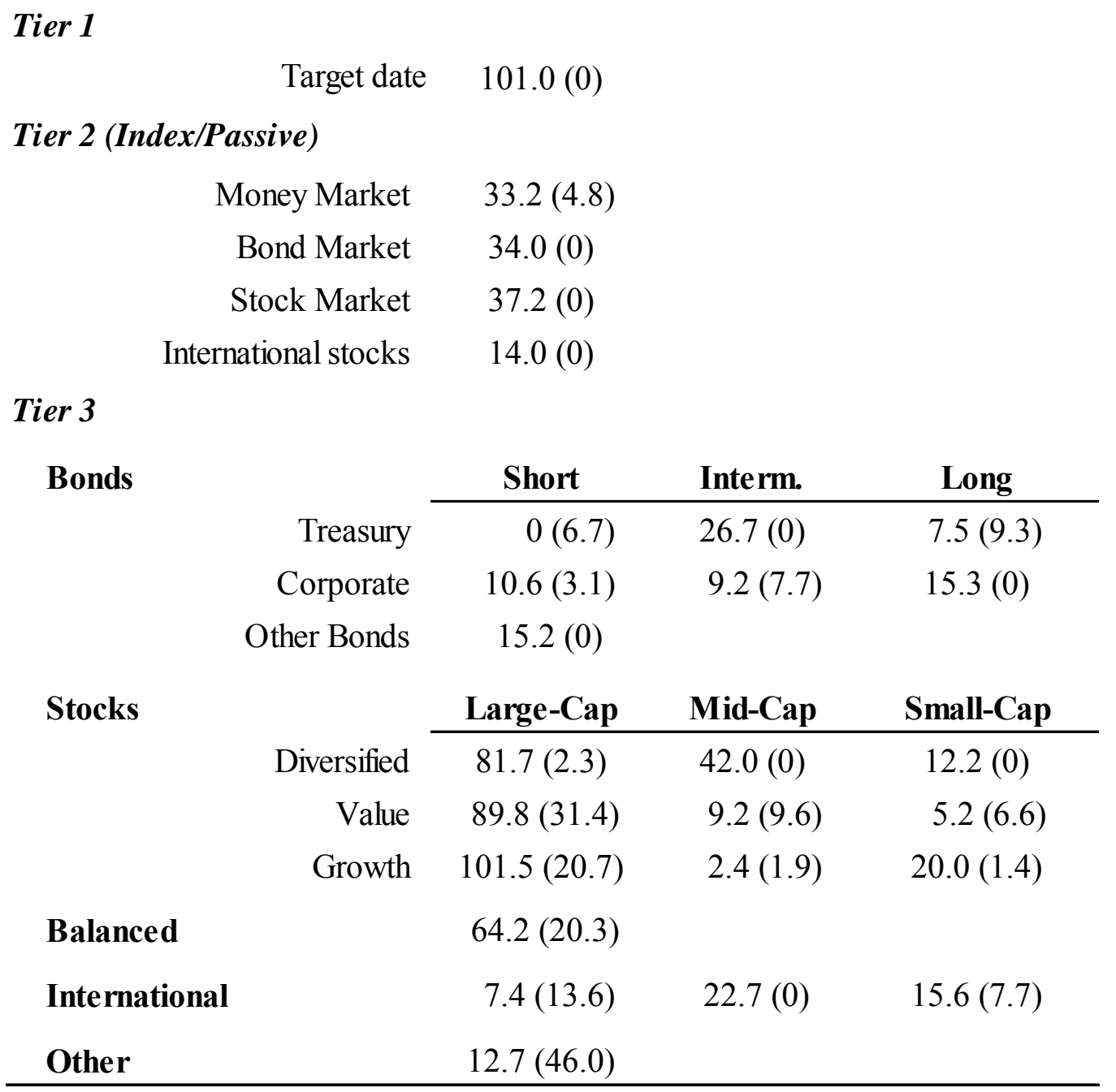

Source: Authors' calculations. 
Table 3. Balances, Number of Participants, and Number of Funds Owned: Streamlined vs Non-Streamlined Participants (as of end-June 2012)

\begin{tabular}{|c|c|c|c|c|c|c|}
\hline \multirow{3}{*}{$\begin{array}{l}\text { Total Balance (\$Millions) } \\
\text { \# Participants }\end{array}$} & \multicolumn{2}{|c|}{$\begin{array}{l}\text { Streamlined Group } \\
\qquad(\mathrm{N}=2,238)\end{array}$} & \multicolumn{2}{|c|}{$\begin{array}{c}\text { Non-Streamlined Group } \\
\qquad(\mathrm{N}=2,371)\end{array}$} & \multicolumn{2}{|c|}{$\begin{array}{c}\text { Overall } \\
(\mathrm{N}=4,609)\end{array}$} \\
\hline & \multicolumn{2}{|c|}{603.8} & \multicolumn{2}{|c|}{380.0} & \multicolumn{2}{|c|}{983.7} \\
\hline & \multicolumn{2}{|c|}{2,238} & \multicolumn{2}{|c|}{2,371} & \multicolumn{2}{|c|}{4,609} \\
\hline \# Funds & \multicolumn{2}{|c|}{87} & \multicolumn{2}{|c|}{47} & \multicolumn{2}{|c|}{87} \\
\hline Contribution (\$, per part.) & Mean & Median & Mean & Median & Mean & Median \\
\hline To all funds & 1,802 & 1,395 & 1,356 & 849 & 1,573 & 1,084 \\
\hline To Deleted funds & 588 & 330 & & & & \\
\hline To Nondeleted funds & 1,214 & 833 & & & & \\
\hline
\end{tabular}

Source: Authors' calculations. 
Table 4. Differences in Mean Characteristics: Streamlined vs Non-Streamlined Participants (as of end-June 2012)

\begin{tabular}{|c|c|c|c|c|}
\hline \multirow{2}{*}{ Age } & \multirow[t]{2}{*}{ Streamlined } & \multirow[t]{2}{*}{$\begin{array}{c}\text { Non- } \\
\text { Streamlined }\end{array}$} & \multicolumn{2}{|c|}{$\begin{array}{c}\text { Difference } \\
\text { (S-NS) }\end{array}$} \\
\hline & & & & \\
\hline $18-30$ & 0.02 & 0.08 & -0.06 & $* * *$ \\
\hline $31-40$ & 0.20 & 0.25 & -0.05 & $* * *$ \\
\hline $41-50$ & 0.33 & 0.29 & 0.04 & $* * *$ \\
\hline $51-60$ & 0.32 & 0.28 & 0.04 & $* * *$ \\
\hline$>60$ & 0.13 & 0.11 & 0.03 & $* * *$ \\
\hline \multicolumn{5}{|l|}{ Gender } \\
\hline Male & 0.55 & 0.45 & 0.10 & $* * *$ \\
\hline Female & 0.45 & 0.55 & -0.10 & $* * *$ \\
\hline \multicolumn{5}{|l|}{ Education } \\
\hline less than graduate school & 0.43 & 0.50 & -0.07 & $* * *$ \\
\hline at least graduate school & 0.41 & 0.33 & 0.08 & $* * *$ \\
\hline \multicolumn{5}{|l|}{ Household Income } \\
\hline low & 0.16 & 0.19 & -0.04 & $* * *$ \\
\hline med & 0.35 & 0.37 & -0.01 & \\
\hline high & 0.46 & 0.39 & 0.07 & $* * *$ \\
\hline Number of Funds & 6.78 & 2.11 & 4.66 & $* * *$ \\
\hline
\end{tabular}

Notes: $* \mathrm{p}<0.10, * * \mathrm{p}<0.05, * * * \mathrm{p}<0.01$. The low income group is defined to have household income of $<\$ 50 \mathrm{~K}$; the middle group $\$ 50-100 \mathrm{~K}$, and the high income group $>\$ 100 \mathrm{~K}$.

Source: Authors' calculations. 
Table 5. Difference in Distribution of Mean Participant Asset Allocations: Streamlined vs Non-Streamlined Participants (as of end-June 2012)

\begin{tabular}{|c|c|c|c|}
\hline \% of contribution in: & $\begin{array}{c}\text { Streamlined } \\
(\mathrm{N}=\mathbf{2 , 2 3 8 )} \\
\end{array}$ & $\begin{array}{l}\text { Nonstreamlined } \\
(\mathbf{N}=\mathbf{2 , 3 7 1 )}\end{array}$ & Difference \\
\hline Stock Funds & 0.45 & 0.28 & $0.18 * * *$ \\
\hline Sector Funds & 0.07 & 0.00 & $0.07 * * *$ \\
\hline Other Funds & 0.01 & 0.00 & $0.01 * * *$ \\
\hline TDF Funds & 0.10 & 0.55 & $-0.46 * * *$ \\
\hline Other Balanced Funds & 0.08 & 0.04 & $0.04 * * *$ \\
\hline International Funds & 0.11 & 0.04 & $0.07 * * *$ \\
\hline Bond Funds & 0.17 & 0.08 & $0.09 * * *$ \\
\hline
\end{tabular}

Note: $* \mathrm{p}<0.10 ; * * \mathrm{p}<0.05 ; * * * \mathrm{p}<0.01$

Source: Authors' calculations. 
Table 6. Difference in Mean Participant Asset Allocations: Post- minus Pre-Streamlining (end-December 2012 vs end-June 2012)

\begin{tabular}{rccc}
\hline & $\begin{array}{c}\text { Plan-Defaulted \& } \\
\text { Streamlined (N=1,616) }\end{array}$ & $\begin{array}{c}\text { Not-Plan-Defaulted \& } \\
\text { Streamlined }(\mathbf{N}=\mathbf{5 6 5})\end{array}$ & $\begin{array}{c}\text { Non-Streamlined } \\
\mathbf{( N = 2 2 9 5})\end{array}$ \\
\hline \% of contribution in: & & & \\
Stock Funds & $-0.188 * * *$ & $-0.043 * * *$ & $-0.004 * *$ \\
Sector Funds & $-0.064 * * *$ & $-0.098 * * *$ & 0.000 \\
Other Funds & $0.002 * * *$ & $0.019 * * *$ & $0.001 * *$ \\
TDF Funds & $0.353 * * *$ & $0.138 * * *$ & 0.002 \\
Other Balanced Funds & $-0.046 * * *$ & -0.004 & 0.000 \\
International Funds & $-0.035 * * *$ & $-0.037 * * *$ & -0.001 \\
Bond Funds & $-0.023 * * *$ & 0.004 & 0.001 \\
Brokerage Account & $0.001 *$ & $0.020 * * *$ & 0.000 \\
\hline
\end{tabular}

Note: ${ }^{*} p<0.10,{ }^{* *} p<0.05,{ }^{* * *} p<0.01$

Source: Authors' calculations 
Table 7. Difference in Mean Participant Asset Allocation by Income:

Post-Streamlining minus Pre-Streamlining (end-Dec 2012 vs end-Jun 2012)

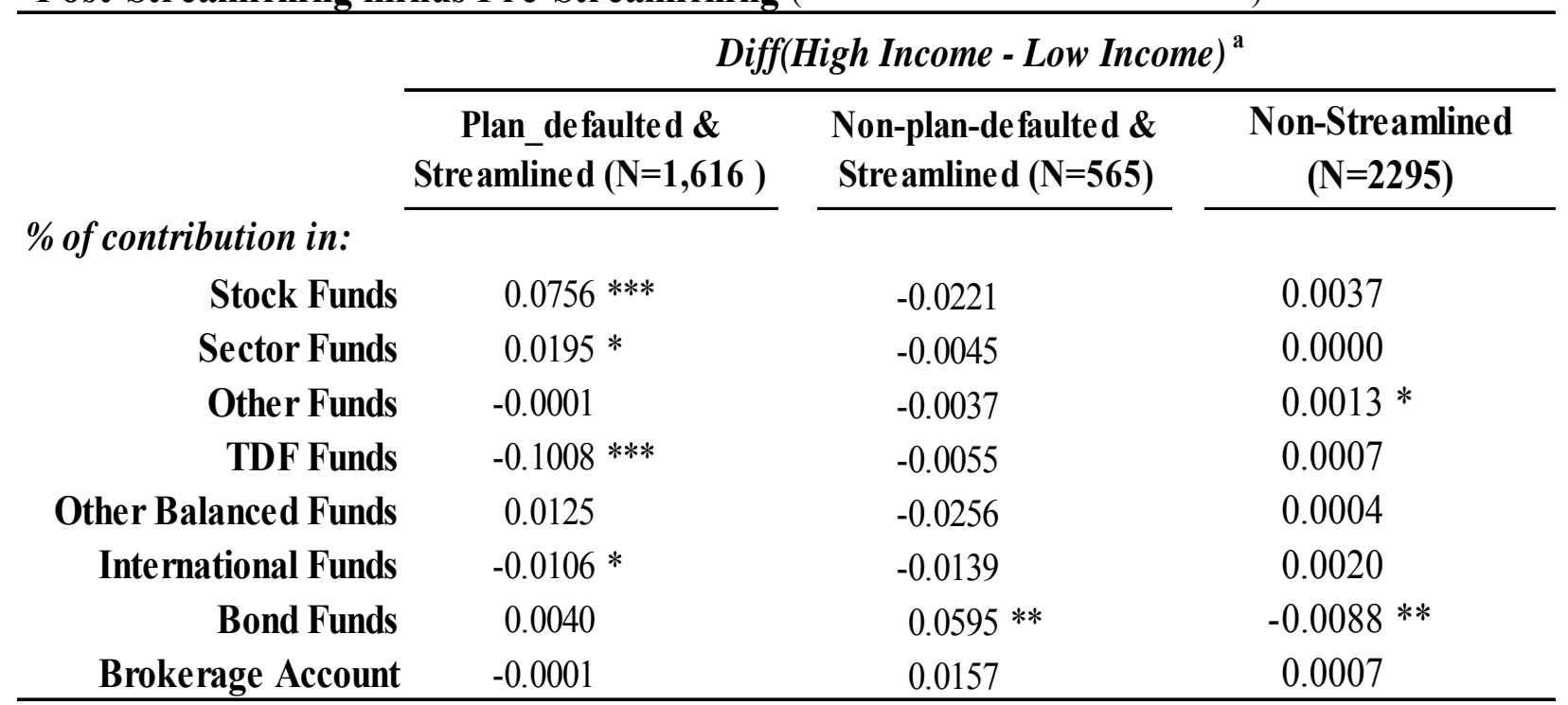

${ }^{a}$ Significance levels: ${ }^{*} \mathrm{p}<0.10,{ }^{* *} \mathrm{p}<0.05,{ }^{* * *} \mathrm{p}<0.01$

Source: Authors' calculations 
Table 8A. Changes in Fraction of Portfolio Invested in Stocks, Annual Turnover, Expense Ratios, and Number Funds Held (end-December 2012 minus end-June 2012 balances)

\begin{tabular}{lrrrrr} 
& & $\Delta \%$ Stock & $\Delta$ Turnover & \multicolumn{1}{c}{$\Delta$ ExpRatio } & $\Delta$ Nfunds \\
\cline { 5 - 6 } Explanatory Variables & Mean & & & & \\
Not-Plan-Defaulted-Streamlined & 0.13 & $-0.0484 * * *$ & $-0.1146 * * *$ & $-0.0595 * * *$ & $-1.4653 * * *$ \\
Plan-Defaulted-Streamlined & 0.36 & $0.0127 * * *$ & $-0.1111^{* * *}$ & $-0.0308 * * *$ & $-1.3179 * * *$ \\
Age & 47.64 & 0.0005 & $0.0044 *$ & -0.0001 & 0.0218 \\
Age**2 & 2383.79 & 0.0000 & $-0.0001 * *$ & 0.0000 & -0.0001 \\
Male & 0.50 & $-0.0077 * *$ & 0.0013 & -0.0020 & $-0.1262 * *$ \\
Education gradschool & 0.37 & -0.0049 & $0.0101 *$ & -0.0018 & -0.0323 \\
HH income low & 0.18 & -0.0001 & -0.0105 & -0.0035 & $0.1173 *$ \\
HH income high & 0.42 & -0.0037 & 0.0052 & 0.0001 & 0.0547 \\
Balance/100k & 2.10 & $0.0015 * *$ & -0.0006 & -0.0002 & -0.0172 \\
N & & 4,476 & 4,447 & 4,476 & 4,476 \\
R-squared & & 0.04 & 0.09 & 0.17 & 0.14 \\
Diff ( $\beta$ (Non-Plan-Def) - $\beta$ (Plan-Def)) & & $-0.0611 * * *$ & -0.0034 & -0.0287 & -0.1473 \\
Mean of dep var & & -0.007 & -0.056 & -0.021 & -0.600 \\
\hline
\end{tabular}

Note: $* \mathrm{p}<0.10, * * \mathrm{p}<0.05, * * * \mathrm{p}<0.01$. Dependent variables as follows: $\Delta \%$ Stock is the $\%$ of the participant's portfolio of funds invested in common stocks; $\Delta$ Turnover measures participant changes in overall annual portfolio turnover (post-pre); $\Delta$ ExpRatio measures the change in annual participant expense ratios (post-pre) and $\Delta \#$ funds measures the change in the number of funds held (post-pre). Values computed for each participant using end-December 2012 minus end-June 2012 balances. Source: Authors' calculations. 
Table 8B. Changes in Fraction of Portfolio Invested in Stocks, Annual Turnover, Expense Ratios, and Number of Funds Held (end-December 2013 minus end-June 2012 balances)

\begin{tabular}{|c|c|c|c|c|c|}
\hline & & $\Delta \%$ Stock & $\Delta$ Turnover & $\Delta$ ExpRatio & $\Delta$ Nfunds \\
\hline Explanatory Variables & Mean & & & & \\
\hline Not-Plan-Defaulted-Streamlined & 0.13 & -0.0072 & $-0.1060 * * *$ & $-0.0478 * * *$ & $-1.4941 * * *$ \\
\hline Plan-Defaulted-Streamlined & 0.36 & $0.0253 * * *$ & $-0.1010 * * *$ & $-0.0171 * * *$ & $-1.2826 * * *$ \\
\hline Age & 47.66 & -0.0015 & -0.0008 & $-0.0078 * * *$ & 0.0132 \\
\hline $\mathrm{Age}^{* * 2}$ & 2384.89 & 0.0000 & 0.0000 & $0.0001 * * *$ & 0.0000 \\
\hline Male & 0.50 & $-0.0156 * * *$ & 0.0007 & $-0.0058 * *$ & $-0.1153 *$ \\
\hline Education gradschool & 0.37 & $-0.0085 *$ & $0.0195 * * *$ & 0.0027 & 0.0074 \\
\hline $\mathrm{HH}$ income low & 0.18 & -0.0046 & 0.0001 & $-0.0069 *$ & 0.0817 \\
\hline $\mathrm{HH}$ income high & 0.42 & -0.0062 & 0.0124 & -0.0045 & 0.0891 \\
\hline Balance/100k & 2.11 & $0.0029 * * *$ & $-0.0067 * * *$ & $-0.0056 * * *$ & $-0.0238 *$ \\
\hline $\mathrm{N}$ & & 4,434 & 4,406 & 4,434 & 4,434 \\
\hline R-squared & & 0.02 & 0.09 & 0.13 & 0.10 \\
\hline $\operatorname{Diff}(\beta$ (Non-Plan-Def) - $\beta$ (Plan-Def $))$ & & $-0.0325 * * *$ & -0.0050 & $-0.0307^{* * *}$ & -0.2115 \\
\hline Mean of dep var & & 0.007 & -0.113 & -0.076 & -0.487 \\
\hline
\end{tabular}

Note: $* \mathrm{p}<0.10, * * \mathrm{p}<0.05, * * * \mathrm{p}<0.01$. Dependent variables as follows: $\Delta \%$ Stock is the $\%$ of the participant's portfolio of funds invested in common stocks; $\Delta$ Turnover measures participant changes in overall annual portfolio turnover (post-pre); $\Delta$ ExpRatio measures the change in annual participant expense ratios (post-pre) and $\Delta \#$ funds measures the change in the number of funds held (post-pre). Values computed for each participant using end-December 2013 minus end-June 2012 balances. Source: Authors' calculations. 
Table 9A. Change in Participant Portfolio Systematic and Idiosyncratic Risk Exposures (end-Dec 2012 minus end-Jun 2012 balances)

\begin{tabular}{|c|c|c|c|c|c|c|c|c|}
\hline & & $\Delta \beta(\mathrm{Mkt})$ & $\Delta \beta(\mathrm{SmB})$ & $\Delta \beta(\mathrm{HmL})$ & $\Delta \beta(\mathrm{WmL})$ & $\Delta \beta($ Term $)$ & $\Delta \beta$ (Def) & $\Delta(\mathrm{RMSE})$ \\
\hline Explanatory Variables & Mean & & & & & & & \\
\hline Not-Plan-Defaulted-Streamlined & 0.13 & $-0.1320 * * *$ & $0.0082 * *$ & $-0.0096 * * *$ & $-0.0188 * * *$ & $-0.0087 * *$ & $-0.0313 * * *$ & $-0.0048 * * *$ \\
\hline Plan-Defaulted-Streamlined & 0.36 & $0.0189 * * *$ & $-0.0072 * * *$ & $-0.0211^{* * *}$ & $-0.0156 * * *$ & $-0.0044 * * *$ & $-0.0162 * * *$ & $-0.0030^{* * *}$ \\
\hline Age & 47.64 & 0.0004 & -0.0001 & $0.0012 * *$ & 0.0001 & 0.0001 & $0.0010 *$ & 0.0000 \\
\hline $\operatorname{Age}^{* * 2}$ & 2383.79 & 0.0000 & 0.0000 & $0.0000 * *$ & 0.0000 & 0.0000 & 0.0000 & 0.0000 \\
\hline Male & 0.50 & $-0.0120 * * *$ & 0.0001 & -0.0007 & $-0.0022 * * *$ & 0.0017 & $-0.0040 * * *$ & $-0.0006 * * *$ \\
\hline Education gradschool & 0.37 & $-0.0089 *$ & -0.0009 & $0.0025 *$ & 0.0000 & 0.0006 & 0.0003 & -0.0002 \\
\hline HH income low & 0.18 & -0.0078 & -0.0004 & 0.0022 & 0.0015 & 0.0014 & 0.0022 & 0.0002 \\
\hline $\mathrm{HH}$ income high & 0.42 & -0.0002 & 0.0009 & 0.0026 & 0.0012 & -0.0002 & 0.0016 & 0.0002 \\
\hline Balance/100k & 2.10 & 0.0001 & $0.0008 * * *$ & 0.0000 & $0.0006 * * *$ & $-0.0008 * * *$ & -0.0005 & 0.0000 \\
\hline $\mathrm{N}$ & & 4,476 & 4,476 & 4,476 & 4,476 & 4,476 & 4,476 & 4,476 \\
\hline R-squared & & 0.100 & 0.012 & 0.050 & 0.089 & 0.009 & 0.052 & 0.142 \\
\hline $\operatorname{Diff}(\beta$ (Non-Plan-Def) - $\beta$ (Plan-Def) $)$ & & $-0.1509 * * *$ & $0.0153 * * *$ & $0.0115 * * *$ & -0.0032 & -0.0043 & $-0.0152 * * *$ & $-0.0018 *$ \\
\hline Mean of dep var & & -0.0145 & -0.0017 & -0.0075 & -0.0079 & -0.0016 & -0.0081 & -0.0017 \\
\hline
\end{tabular}

Note: ${ }^{*} \mathrm{p}<0.10,{ }^{* *} \mathrm{p}<0.05,{ }^{* *} \mathrm{p}<0.01$. Post-Pre dependent variables measured as follows: $\Delta \beta(\mathrm{Mkt})$ measures changes in participants' exposure to market risk; $\Delta \beta(\mathrm{SmB})$ measures changes in participants' exposure to the difference in performance of small relative to big stocks; $\Delta \beta(\mathrm{HmL})$ measures changes in participants' exposure to the difference in performance of value stocks to growth stocks; ; $\Delta \beta$ (Term) refers to changes in participants' exposure to the difference in returns on a market portfolio of long-term corporate bonds and the one-month Treasury bill rate measured at the end of the previous month; and $\Delta \beta$ (Def) measures changes in participants' exposure to the difference between the monthly long-term government bond return and the one-month Treasury bill rate; and $\triangle$ RMSE is the standard deviation of the residuals from the 6-factor model in section 5.2. Values are computed for each participant using end-December 2012 minus end-June 2012 balances. Source: Authors' calculations; see variable descriptions in text. 
Table 9B. Change in Participant Portfolio Systematic and Idiosyncratic Risk Exposures (end-Dec 2013 minus end-Jun 2012 balances)

\begin{tabular}{|c|c|c|c|c|c|c|c|c|}
\hline & & $\Delta \beta(\mathrm{Mkt})$ & $\Delta \beta(\mathrm{SmB})$ & $\Delta \beta(\mathrm{HmL})$ & $\Delta \beta(\mathrm{WmL})$ & $\Delta \beta($ Term $)$ & $\Delta \beta$ (Def) & $\Delta(\mathrm{RMSE})$ \\
\hline Explanatory Variables & Mean & & & & & & & \\
\hline Not-Plan-Defaulted-Streamlined & 0.13 & $0.0512 * * *$ & $0.0057 * *$ & $0.0051 *$ & -0.0002 & $-0.0174 * * *$ & $-0.0136 * * *$ & $-0.0007 * * *$ \\
\hline Plan-Defaulted-Streamlined & 0.36 & $0.0372 * * *$ & $0.0029 * *$ & $0.0041 * * *$ & $-0.0007 *$ & $-0.0028 *$ & $-0.0051 * * *$ & $-0.0004 * * *$ \\
\hline Age & 47.66 & $-0.0257 * * *$ & 0.0006 & $0.0014 * * *$ & $-0.0003 * *$ & -0.0002 & -0.0001 & $-0.0002 * * *$ \\
\hline Age**2 & 2384.89 & $0.0002 * * *$ & 0.0000 & $0.0000 * * *$ & $0.0000 * * *$ & 0.0000 & 0.0000 & $0.0000 * * *$ \\
\hline Male & 0.50 & $-0.0224 * *$ & 0.0004 & 0.0013 & -0.0001 & 0.0015 & -0.0009 & $-0.0003 * * *$ \\
\hline Education gradschool & 0.37 & 0.0137 & 0.0009 & -0.0011 & -0.0005 & 0.0016 & 0.0013 & 0.0001 \\
\hline $\mathrm{HH}$ income low & 0.18 & -0.0044 & -0.0009 & 0.0016 & $-0.0008 *$ & 0.0023 & $0.0045 * * *$ & 0.0001 \\
\hline HH income high & 0.42 & $-0.0310 * * *$ & 0.0025 & 0.0001 & 0.0000 & 0.0008 & -0.0003 & -0.0001 \\
\hline Balance/100k & 2.11 & $-0.0161 * * *$ & 0.0004 & 0.0002 & $0.0003 * * *$ & $-0.0010 * *$ & $-0.0006 * *$ & $-0.0001 * * *$ \\
\hline $\mathrm{N}$ & & 4,433 & 4,433 & 4,433 & 4,433 & 4,433 & 4,433 & 4,433 \\
\hline R-squared & & 0.063 & 0.008 & 0.006 & 0.029 & 0.028 & 0.026 & 0.041 \\
\hline $\operatorname{Diff}(\beta$ (Non-Plan-Def) - $\beta$ (Plan-Def $))$ & & 0.0141 & 0.0027 & 0.0010 & 0.0006 & $-0.0146 * * *$ & $-0.0085 * * *$ & $-0.0003 *$ \\
\hline Mean of dep var & & -0.1897 & 0.0128 & 0.0095 & 0.0017 & -0.0171 & -0.0130 & -0.0016 \\
\hline
\end{tabular}

Note: ${ }^{*} \mathrm{p}<0.10,{ }^{* *} \mathrm{p}<0.05,{ }^{* *} \mathrm{p}<0.01$. Post-Pre dependent variables measured as follows: $\Delta \beta(\mathrm{Mkt})$ measures changes in participants' exposure to market risk; $\Delta \beta(\mathrm{SmB})$ measures changes in participants' exposure to the difference in performance of small relative to big stocks; $\Delta \beta(\mathrm{HmL})$ measures changes in participants' exposure to the difference in performance of value stocks to growth stocks; ; $\Delta \beta$ (Term) refers to changes in participants' exposure to the difference in returns on a market portfolio of long-term corporate bonds and the one-month Treasury bill rate measured at the end of the previous month; $\Delta \beta$ (Def) measures changes in participants' exposure to the difference between the monthly long-term government bond return and the one-month Treasury bill rate; and $\triangle \mathrm{RMSE}$ is the standard deviation of the residuals from the 6-factor model in section 5.2. Values are computed for each participant using end-December 2013 minus end-June 2012 balances. Source: Authors' calculations; see variable descriptions in text. 